\title{
Report of an 18-Month-Old Male Infant with Unilateral Bloody Nipple Discharge
}

\author{
18 Aylık Erkek Bebekte Tek Taraflı Kanlı Meme Başı Akıntısı Olgusu
}

Asiye Şafak BULUT'1 , Levent AKGÜNGÖR², Serdar YÜKSEL³

\author{
${ }^{1}$ TOBB ETÜ Hospital, Department of Pathology, Ankara, Turkey \\ 2TOBB ETÜ Hospital, Department of Pediatrics, Ankara, Turkey \\ ${ }^{3}$ TOBB ETÜ Hospital, Department of Radiology, Ankara, Turkey
}

\begin{abstract}
Bloody nipple discharge (BND) is a rare, distressing finding in infants. It is mostly associated with benign mammary duct ectasia and resolves spontaneously. Here we report an 18-month-old male presented with unilateral BND. Ultrasonography revealed a cystic mass with thin septations under the nipple. Microbiological examination showed no evidence of infection. Cytologic examination revealed hemosiderin-laden macrophages and some inflammatory cells on a bloody background. Clinical, radiological and laboratory findings supported mammary duct ectasia and a follow-up without treatment for six to nine months was recommended. The condition gradually disappeared over a period of three months, both clinically and ultrasonographically.
\end{abstract}

Key Words: Infant, Nipple, Nipple aspirate fluid

\section{ÖZET}

Kanlı meme başı akıntısı, küçük çocuklarda endişe verici bir bulgu olup genellikle memenin benign duktal ektazisi ile ilişkili, kendiliğinden iyileşen bir durumdur. Burada tek taraflı kanlı meme başı akıntısı şikayeti ile başvuran 18 aylık bir erkek bebek hasta sunulmaktadır. Ultrasonografide meme bașı altında ince septalı kistik kitle saptanmıştır. Akıntının mikrobiyolojik incelemesinde infeksiyon yönünde bir bulgu izlenmemiş, sitolojik incelemesinde kanlı zeminde hemosiderin içeren makrofajlar ve az sayıda iltihap hücresi tespit edilmiştir. Klinik, radyolojik ve laboratuvar bulguları memenin benign duktal ektazisi ile uyumlu olarak değerlendirilmiş, hastanın 6-9 ay arası tedavisiz izlemi önerilmiştir. Akıntı 3 ay içinde kendiliğinden azalarak klinik ve radyolojik olarak tamamen ortadan kalkmıştır.

Anahtar Sözcükler: Bebek, Meme başı, Meme aspirat SIVISI

\section{INTRODUCTION}

BND is a very rare symptom in infants and its occurrence is distressing for the family. Although it is associated with intraductal papilloma or breast carcinoma in adults, it is mostly idiopathic or associated with benign mammary duct ectasia in infants and children. Follow-up without treatment and abstaining from invasive diagnostic procedures is considered to be the best course of action for these patients.

\section{CASE REPORT}

An 18-month-old male presented with BND from his right nipple that had continued for one month. There was no his- tory of trauma. His past medical history was unremarkable. On physical examination, dark red to brown serosanguineous fluid was leaking through palpation of the right breast. There was no palpable mass in the breasts. There were no clinical signs of inflammation. Prolactin, estrogen and thyrotropin levels were within the normal ranges. An ultrasound of the right breast revealed a cystic mass, measuring $8 \times 6 \times 3.5 \mathrm{~mm}$, with thin septations under the nipple. In the microbiological examination, no microorganism was observed with gram stain. Cultures were also negative. Cytologically, the fluid contained hemosiderin-laden macrophages, some lymphocytes, plasmocytes, and eosinophilic and neutrophilic leucocytes. No atypical cells or ductal epithelial cells were observed. As clinical, radiological and laboratory findings suggested mammary duct ectasia, a follow-up of six to nine months; in the case of no regression, 
pediatric surgery consultation was recommended. BND gradually decreased over a period of three months, and disappeared clinically and ultrasonographically.

\section{DISCUSSION}

BND in infancy was first reported by Berkowitz et al in 1983 and a few case have been reported so far. In the early cases, subcutaneous mastectomy was generally performed in patients with BND and histological diagnosis was mammary duct ectasia (1-6). Although these patients were over-treated with surgery, histological examinations highlighted their benign nature. After then most of the later cases were followed-up and resolved without any treatment (7-12).

Possible etiologies of BND were evaluated by Imamoğlu et al (13). In their study, 14 breasts of 11 patients were examined. Patient ages were between three months and 12 years (Mean: 3.8 years). Some of them had cystic palpable masses under the areola. Hormone levels were normal in all patients. The BND resolved with a two-week course of oral antibiotic therapy in one patient, and without any medical treatment in two patients. Surgical intervention was performed for the remaining eight patients on a total of ten breasts. Histological findings showed that the etiology of the BND was a duct ectasia in five biopsies, infantile gynecomastia in three and fibrocystic changes in two. Gross examination of the duct ectasia cases revealed bloodfilled cysts.

As BND is an alerting symptom for parents and clinicians, a diagnostic approach is needed for the selection of appropriate therapy. Kelly et al. (10) recommended an initial workup including Gram-stain, culture and cell count of the discharge, serum levels of prolactin, estradiol, and thyrotropin, and an ultrasound of the affected breast. If hormone levels are abnormal, an endocrine consultation and cranial MRI is recommended. If the culture is positive, or if the clinical picture suggests infection, treatment for mastitis is recommended. If an ultrasound of the breast reveals a mass or abnormality other than mammary duct ectasia, a pediatric surgery consultation versus watchful waiting is recommended. If hormone levels are within normal limits, the culture and Gram-stain are negative, and an ultrasound reveals normal breast tissue or mammary duct ectasia, then observational follow-up is suggested. Imamoglu et al. (13) approved a similar diagnosis and treatment algorithm for breasts with BND according to sex, physical examination findings and ultrasonography evaluation. According to this chart, the first step is culture. If the culture is positive, treatment with antibiotics and a follow up are recommended. If the culture is negative with normal physical and ultrasonography findings, follow up without any treatment is recommended. However, if there are palpable masses or diffuse enlargement of the breast, especially in a male patient, then surgical treatment with a simple mastectomy or excisional biopsy is recommended.

Here, we reported unilateral BND in an 18-month-old male, discussed the possible etiologies and diagnostic approaches under the light of the literature. Our patient recovered without any treatment. It is important to know that BND in infants is mostly due to duct ectasia, and invasive procedures must be avoided in these patients.

\section{REFERENCES}

1. Berkowitz CD, Inkelis SH. Bloody nipple discharge in infancy. J Pediatr 1983;103:755-6.

2. Stringel G, Perelman A, Jimenez C. Infantile mammary duct ectasia: A cause of bloody nipple discharge. J Pediatr Surg 1986;21:671-4.

3. Miller JD, Brownell MD, Shaw A. Bilateral breast masses and bloody nipple discharge in a 4-year-old boy. J Pediatr 1990;116: 744-7.

4. Böber $E$, Ozer $E$, Akgür $F$, Büyükgebiz A. Bilateral breast masses and bloody nipple discharge in a two-year-old boy. J Pediatr Endocrinol Metabol 1996;9:419-21.

5. Kitahara S, Wakabayashi M, Shiba T, Nonaka K, Nonaka H, Kobayashi I. Mammary duct ectasia in children presenting bloody nipple discharge: A case in a pubertal girl. J Pediatr Surg 2001;36:E2.

6. Al-Arfai AA, Chir AF, Mitra DK, Sowayan SA. Bloody nipple discharge in a 4-year old child. Ann Saudi Med 2003;23:175-6.

7. Leung AK, Kao CP. Mammary duct ectasia: A cause of bloody nipple discharge. J Natl Med Assoc 2004;96:543-5.

8. Nili F, Tajaddini A. Bloody nipple discharge in infancy: Report of a case. Acta Medica Iranica 2004;42:232-4.

9. Çorapçıŏlu F, Akansel G, Sarper N, Taneri H, Yıldız K. Mammary duct ectasia as a cause of bloody nipple discharge in a 28-monthold boy. Turk J Pediatr 2005;47:379-81.

10. Kelly VM, Arif K, Ralston S, Greger N, Scott S. Bloody nipple discharge in an infant and a proposed diagnostic approach. Pediatrics 2006;117:e814-6.

11. De Praeter C, De Coen K, Vanneste K, Vanhaesebrouck P. Unilateral bloody nipple discharge in a two-month-old male. Eur $\mathrm{J}$ Pediatr 2008;167:457-9.

12. Gupta V, Yadav SK. Infantile bloody nipple discharge: A case report and review of the literature. Afr J Paediatr Surg 2009;6:63-4.

13. Imamoglu M, Cay A, Reis A, Ozdemir O, Sapan L, Sarihan H. Bloody nipple discharge in children: Possible etiologies and selection of appropriate therapy. Pediatr Surg Int 2006;22:158-63. 